\title{
A new species of Tityus C.L. Koch, 1836 (Scorpiones: Buthidae) from the island of Martinique, Lesser Antilles
}

\author{
Новый вид рода Tityus C.L. Koch, 1836 (Scorpiones: Buthidae) \\ с острова Мартиники (Малые Антильские острова)
}

\author{
Wilson R. Lourenço \\ Вильсон Р. Аоуренсо
} Muséum national d’Histoire naturelle, Département Systématique et Evolution, UMR7205, CP 053, 57 rue Cuvier, 75005 Paris, France.
Национальный музей естественной истории, Париж, Франция.

KEY-WORDS: Scorpiones, Buthidae, Tityus, new species, Martinique, endemic.

КЛЮЧЕВЫЕ СЛОВА: Scorpiones, Buthidae, Tityus, новый вид, Мартиника, эндемик.

ABSTRACT. Tityus marechali sp.n. is described from the island of Martinique, Lesser Antilles. It is tentatively placed in the subgenus Tityus s.str. pending further studies on intrageneric classification. The new species, described from two males and three females taken in a patch of secondary or pristine tropical forest in the region of Grande Anse, seems to be a local endemic.

РЕЗЮМЕ. Описан Tityus marechali sp.n. с острова Мартиники (Малые Антильские острова). Он временно помещен в состав подрода Tityus s.str. впредь до проведения новых исследований по внутриродовой классификации. Новый вид, описанный по двум самцам и трем самкам, собранным на участке вторичного и девственного тропического леса в районе Гранд-Анз.

\section{Introduction}

The genus Tityus C.L. Koch, 1836 is the most speciose among all scorpion genera [Lourenço, 2006]. This group is exclusively Neotropical and it is markedly present in most of the tropical and subtropical regions of South America. To a lesser extent, the genus also populates Central America, but not north of Costa Rica. Several species are known from the Caribbean area, but most are restricted to the Greater Antilles [Lourenço, 1992]. Only a few Tityus have been described from the Lesser Antilles, i.e., T. insignis (Pocock, 1889) from St. Lucia, T. pictus Pocock, 1893 from St. Vincent, T. smithii Pocock, 1897 and T. atriventer Pocock, 1897, both latter from Grenada [Pocock, 1889, 1893, 1897].

Several years ago, in a paper about the Tityus species described from the Lesser Antilles, I attempted to revise the status of some of these species [Lourenço, 1984]. In my conclusions, I suggested that the very closely related forms represented by $T$. pictus, $T$. smithii and T. smithii microdon Pocock, 1893 probably corresponded to local races of a single polymorphous species. In fact, previously to this, Kraepelin [1899] had already suggested $T$. smithii to be a subspecies of $T$. pictus. However, since I did not formally synonymize these 'subspecies', other authors continued to recognize them and even listed all in the Catalog of the Scorpions of the World [Fet \& Lowe, 2000]. In a recent article, Teruel [2011] proposed a revision of the taxonomic status of $T$. pictus and T. smithii, based on a more freshly collected material, and concluded that both species were valid, rejecting at the same time any possibility of polytypism or polymorphism among these populations. He confirmed, however, T. smithii microdon to be a junior synonym of $T$. smithii.

It is not my aim to reopen any possible polemics about the status of these Tityus populations. I only propose the description of a new Tityus species from the island of Martinique. This new species is similar to T. pictus and represents the first 'living' Tityus population to be confirmed for Martinique. My previous description of $T$. exstinctus Lourenço from the North of the island was based on very old material from a population which most certainly vanished after the eruption of Mount Pelée in 1902 [Lourenço, 1995].

\section{Material and methods}

Holotype and three paratypes are deposited in the Muséum national d'Histoire naturelle, Paris. One paratype is housed in the Zoological Museum, State University of Moscow, Russia. Scorpions were collected with the use of pitfall traps. Illustrations and measurements were made with the aid of a Wild M5 stereomicroscope with a drawing tube (camera lucida) and an ocular micrometer. Measurements follow Stahnke [1970] and are given in mm. Line drawings and photographs are not executed to scale. Trichobothrial notations follow Vachon [1974] while the morphological 
terminology mostly follows Vachon [1952] and Hjelle [1990].

\section{Taxonomic part}

Family Buthidae C.L. Koch, 1837

Genus Tityus C.L. Koch, 1836

Subgenus Tityus s.str.

Tityus marechali sp.n.

Figs 1-10.

HOLOTYPE $\odot$, Lesser Antilles, Martinique, Grande Anse, $14^{\circ} 29^{\prime} 40^{\prime \prime} \mathrm{N}, 61^{\circ} 04^{\prime} 40^{\prime \prime} \mathrm{W}, 30.01 .2013$, leg. P. Marechal.

PARATYPES: $1 \sigma^{7}$, same locality, 3.04.2012; $1 \sigma^{7}$ subadult, same locality, 17.08.2012; 1 ㅇ, same locality, $31.10-10$ 13.11.2012; 1 \% , same locality, 10.01.2013, all leg. P. Marechal.

NAME. Honours my colleague Patrick Marechal (now based in Martinique), who collected the new species.

DIAGNOSIS. Scorpion of medium size, total length $54\left(\mathrm{O}^{7}\right)$ and $62 \mathrm{~mm}(+)$. Coloration yellow to reddishyellow with body and appendages intensely spotted. Granulation weak to moderate throughout body and appendages. Subaculear tubercle extremely reduced, almost absent in $\sigma^{T}$. All pedipalp carinae complete; dorso- and ventro-internal carinae on patella with several strong spinoid granules, these being better marked in + . Fixed and movable fingers of pedipalps with 12 rows of granules in both sexes. Pectinal teeth count 23 in $\sigma^{7}$ and $21 / 22$ in 9 .

RELATIONSHIPS. By its general coloration and morphological pattern, the new species shows clear affinities to $T$. pictus, this latter being endemic to the island of St. Vincent. The two species can, however, be distinguished by a number of features: (i) several distinct morphometric values, (ii) a slightly higher number of pectinal teeth, (iii) only 12 rows of granules on the fixed and movable fingers of chela pedipalp, (iv) stronger spinoid granules on the internal surface of the pedipalp patella in T. marechali sp.n.

DESCRIPTION. Coloration basically yellow to reddish-yellow (Fig. 10). Prosoma: carapace yellow with reddish-brown spots better developed around median eyes which are strongly marked with black pigment. Mesosoma: tergites I-VII yellowish with reddish-brown spots arranged in about three longitudinal strips, moderately marked. Metasomal segments I to III yellow with diffused brownish spots on lateral and ventral surfaces; segments IV and V dark reddish to dark brown. Vesicle reddish with extremity of aculeus darker. Venter yellowish with diffused reddish spots over sternites. Chelicerae yellowish with a dark variegated pigmentation, better marked in anterior region; fingers dark reddish. Pedipalps and legs yellowish with diffused brownish spots.

Carapace moderately granular; anterior margin with a median concavity. Anterior median superciliary and posterior median carinae moderately developted. All furrows moderately deep. Median ocular tubercle anterior to centre of carapace. Three pairs of lateral eyes. Sternum triangular. Mesosoma: tergites moderately granular; granulations better marked in $\sigma^{7}$. Median carina moderate on all tergites. Tergite VII pentacarinate. Venter: genital operculum broader than long, divided into two semi-triangular plates. Pectines: pectinal teeth count 21-21 (holotype), 23-23 ( $\sigma^{7}$ paratype), basal middle lamellae of pectines strongly dilated in + , pentagonal in shape, but only slightly dilated in $\sigma^{\prime}$. Sternites smooth with elongate spiracles; VII with 4 weakly developed carinae. Metasomal segment I with ten carinae; segments II-IV each with eight carinae; segment $\mathrm{V}$ with five carinae. Intercarinal spaces weakly granular. Telson (Figs $7 \& 8$ ) with moderate to weak granulations on ventral and lateral surfaces; aculeus long and strongly curved; subaculear tooth extremely reduced, vestigial in $\sigma^{7}$. Cheliceral dentition characteristic of Buthidae (Fig. 6); ventral teeth on movable finger reduced, but distinct [Vachon, 1963]; ventral face of both fingers and manus densely covered with long setae. Pedipalps: femur pentacarinate; patella with seven carinae; chela with nine carinae; all carinae moderately to strongly developed; intercarinal tegument weakly granular; some strong granules present on internal surface of chela hand. Fixed and movable fingers with 12 oblique rows of granules in both sexes. Trichobothriotaxy (Figs 1-5); orthobothriotaxy A- $\alpha-$ alpha [Vachon, 1974, 1975]. Legs: tarsus with numerous, short, fine setae ventrally.

TAXONOMIC COMMENTS. When I suggested that T. pictus, T. smithii and T. smithii microdon could correspond to local races of a single polymorphous species, this example did not constitute an isolate case. In fact, for a number of species of Tityus different types of polymorphism have since been demonstrated [Lourenço, 1988; Lourenço \& Eickstedt, 1988]. Polymorphism is also known for species of other buthid genera [Lourenço et al., 2011]. Polymorphism is most frequently expressed through variability in patterns of coloration and morphometric values. This latter character is the key one used to define the Tityus species from the Lesser Antilles by Pocock [1893] and again to confirm the validity of these species by Teruel [2011].

As far as no final response is available how to precisely define the status of the several Tityus populations from the Lesser Antilles, two situations can be suggested: (i) The morphological differences observed for the different populations are stable, as suggested by Teruel [2011], consequently these do represent distinct and valid species, including the one from Martinique; (ii) The existence of polymorphism will finally be established (maybe with the support of molecular techniques); in this case, the population from Martinique should only be considered as part of this polymorphic complex.

Morphometric values (in $\mathrm{mm}$ ) of $O$ holotype/ $\sigma^{x}$ paratype of Tityus marechali sp.n. Total length (including telson) 62.4/53.6. Carapace: length 7.0/6.1; anterior width 4.9/4.3; posterior width 7.3/6.7. Meso- 


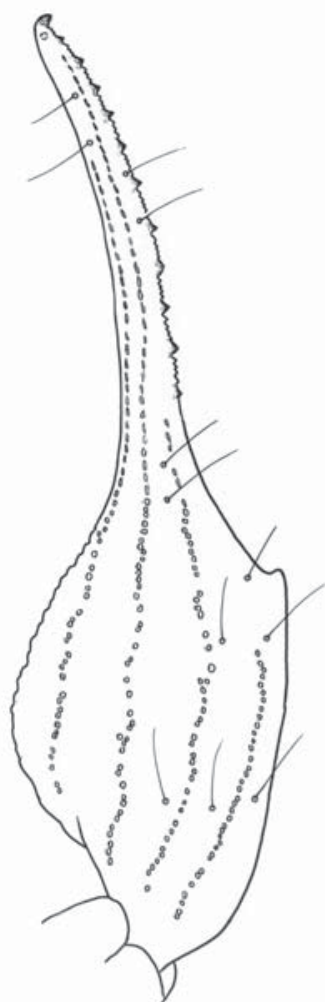

1


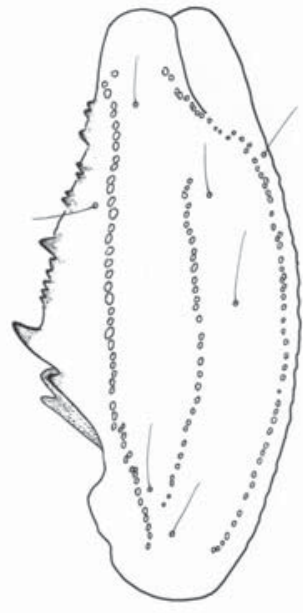

3

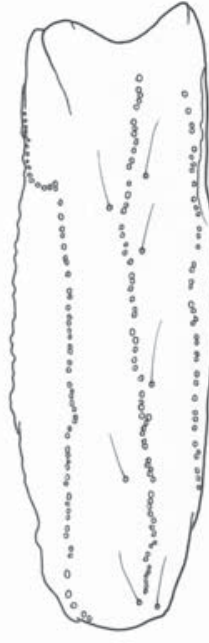

4

Figs 1-5. Tityus marechali sp.n., holotype, trichobothrial pattern: $1 \& 2$ - chela, dorso-external and ventral aspects, respectively; $3 \&$ 4 - patella, dorsal and external aspects, respectively; 5 - femur, dorsal aspect.

Рис. 1-5. Tityus marechali sp.n., голотип, характер распределения трихоботрий: 1, 2 - хела, соответственно одновременно сверху и снаружи, а также снизу; 3,4 - пателла, соответственно сверху и снаружи; 5 - бедро, сверху.

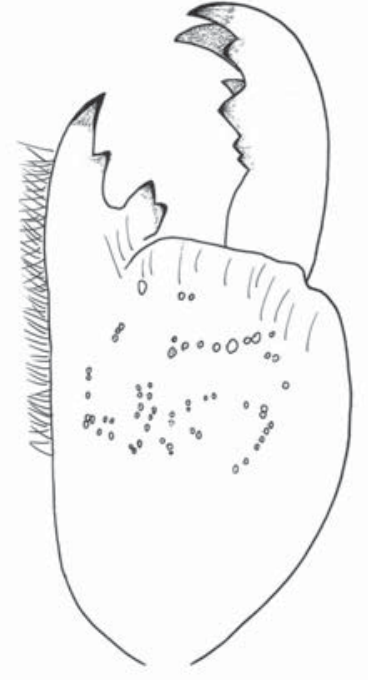

6

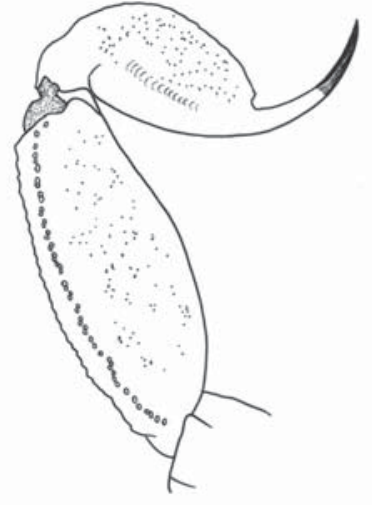

7

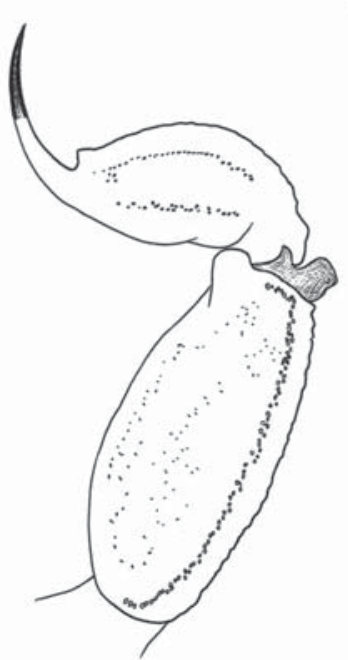

8

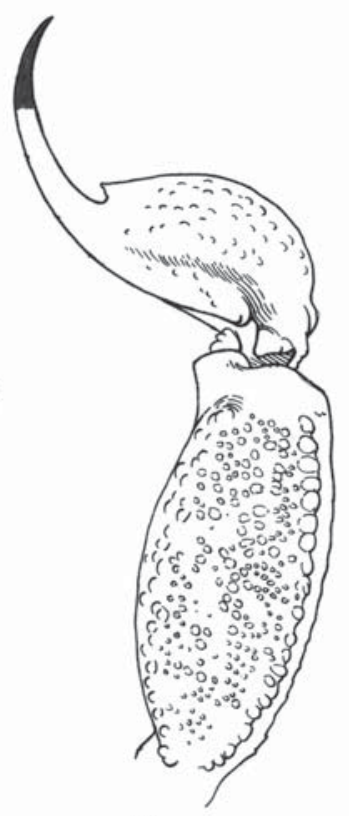

9

Figs 6-9. Tityus marechali sp.n., holotype (6 \& 8) and $0^{7}$ paratype (7), and Tityus pictus Pocock, 1893, 9 (9): 6 — chelicera, dorsal aspect. $7 \& 8$ - metasomal segment $\mathrm{V}$ and telson, lateral aspect; 9 - same.

Рис. 6-9. Tityus marechali sp.n., голотип $(6,8)$ и паратип О (7), и Tityus pictus Pocock, 1893, 9 (9): 6 — хелицера, сверху; 7, 8 сегмент V метасомы и тельсон, сбоку; 9 - то же. 


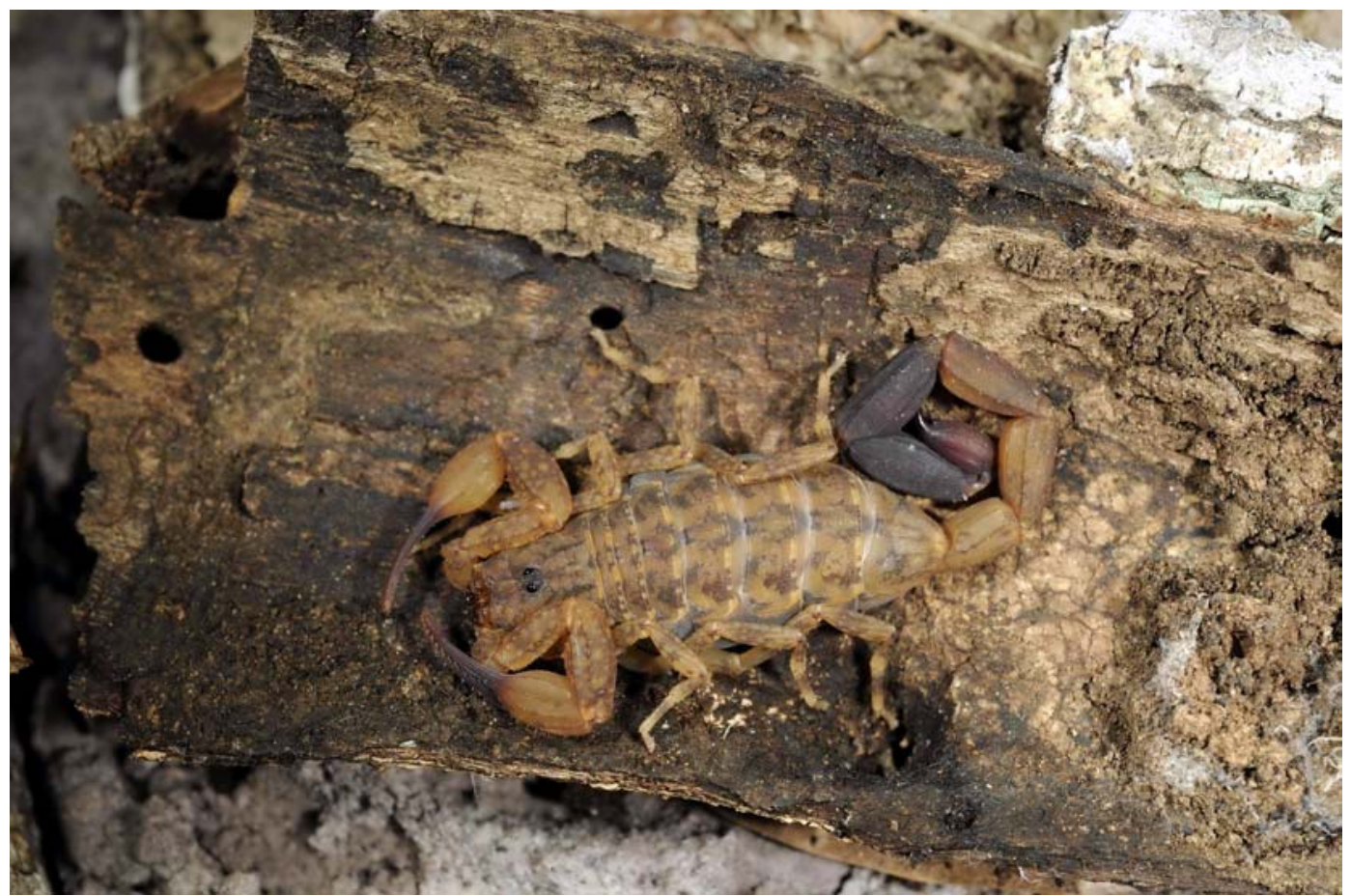

Fig. 10. Tityus marechali sp.n., holotype alive in the field.

Рис. 10. Tityus marechali sp.n., живой голотип в природе.

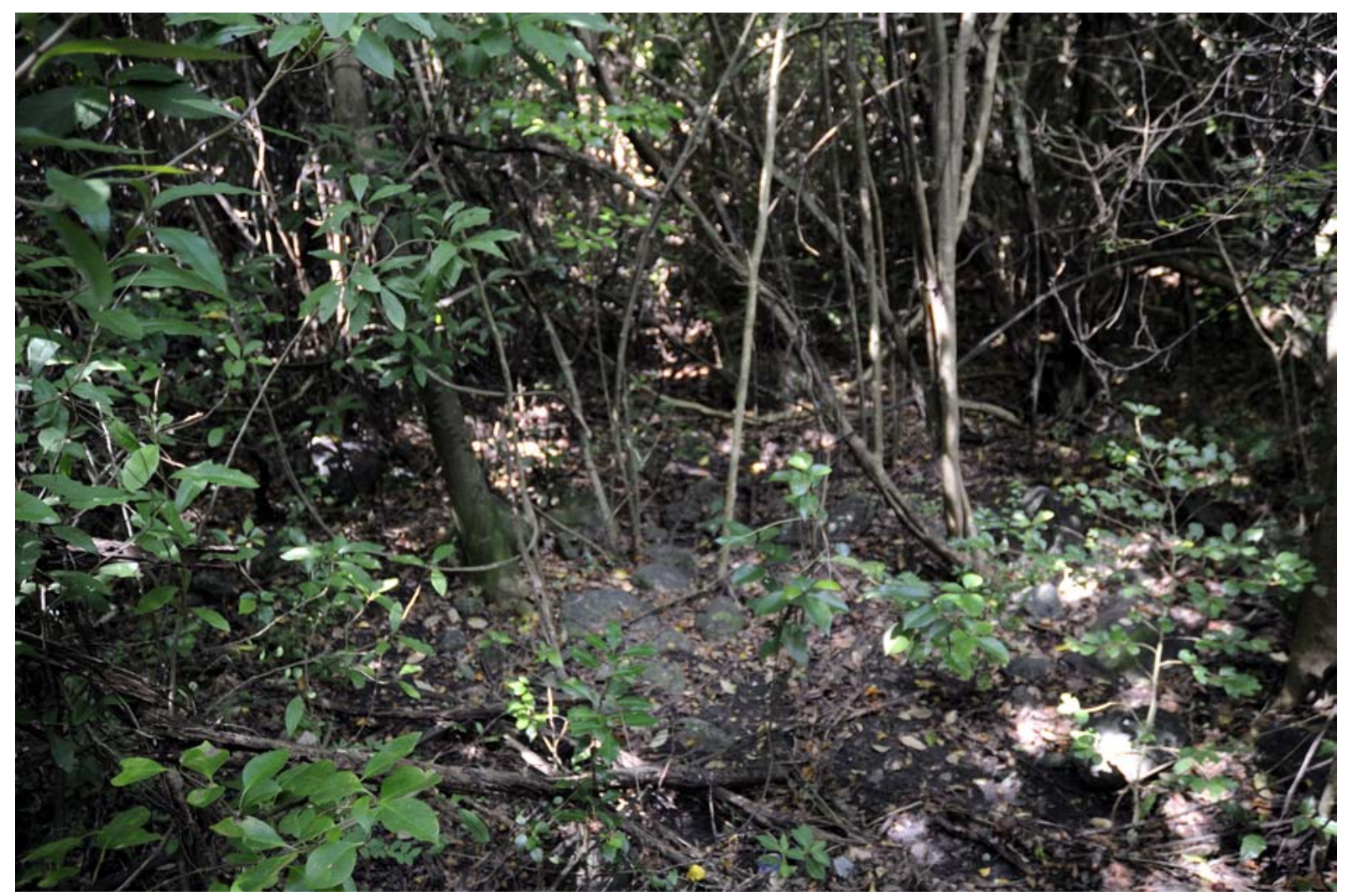

Fig. 11. The habitat composed of primary and secondary forest, whence Tityus marechali sp.n. has been taken. The stones on the ground are possible shelters for the scorpion.

Рис. 11. Биотоп, состоящий из первичного и вторичного леса, откуда был собран Tityus marechali sp.n. Возможно, камни на земле служат укрытиями для этого скорпиона. 
soma length 16.8/12.0. Metasomal segment I: length 4.9/44, width $3.6 / 3.2$; V: length $7.5 / 7.0$, width $3.3 / 2.9$, depth $3.3 / 2.8$. Telson length $6.6 / 5.9$; vesicle width $2.7 /$ 2.3, depth 2.6/2.3. Pedipalp: femur length $6.2 / 5.7$, width $2.2 / 2.0$; patella length $7.2 / 6.4$, width $3.1 / 2.9$; chela length $12.9 / 11.5$, width $3.5 / 2.9$, depth $3.0 / 2.6$; movable finger length 7.9/7.2.

ECOLOGICAL REMARKS. The habitat whence Tityus marechali sp.n. has been collected is a typical dry forest with bushes, the canopy reaching a maximum of 4 to $5 \mathrm{~m}$ above ground-level. There is a mixture of both primary and secondary forest in the area. A number of stones are scattered on the ground and these may represent shelters for the scorpion species (Fig. 11).

ACKNOWLEDGEMENTS. I am most grateful to Patrick Marechal (Martinique), who collected and sent me for study the material of this new species. In addition, he has provided general information on its ecology and allowed to use several of his personal photographs. My thanks also go to Sergei Golovatch, Russian Academy of Sciences, Moscow for his interest in the publication of this article.

\section{References}

Fet V., Lowe G. 2000. Family Buthidae C.L. Koch, 1837 // Fet V., Sissom W.D., Lowe G., Braunwalder M.E. (eds). Catalog of the scorpions of the world (1758-1998). New York: The New York Entomological Society. P.54-286.

Hjelle J.T. 1990. Anatomy and morphology // Polis G.A. (ed.). The Biology of Scorpions. Stanford: Stanford University Press. P.9-63.

Kraepelin K. 1899. Scorpiones und Pedipalpi // Dahl F. (ed.). Das Tierreich. Herausgegeben von der Deutschen zoologischen Gesellschaft. Berlin: R. Friedländer und Sohn Verlag. Bd.8 (Arachnoidea). S.1-265.

Lourenço W.R. 1984. Considérations sur les espèces de Tityus (Scorpiones, Buthidae) décrites des Petites Antilles // Revue Arachnologique. T.5. P.91-105.

Lourenço W.R. 1988. Diversité biologique et modalités de la spéciation chez les scorpions amazoniens; Tityus silvestris Pocock, un cas particulier de polymorphisme // Comptes Rendus des Séances de l'Académie des Sciences, Paris. T.306. P.463-466.

Lourenço W.R. 1992. Les peuplements des scorpions des Antilles; facteurs historiques et écologiques en association avec les straté- gies biodémographiques // Studies on Neotropical Fauna and Environment. Vol.27. P.43-62.

Lourenço W.R. 1995. A remarkable finding of a new species of Tityus from Martinique in Lesser Antilles (Chelicerata, Scorpiones, Buthidae) // Anales del Instituto de Biologia, UNAM, Ser. Zool. T.66. P.27-32.

Lourenço W.R. 2006. Nouvelle proposition de découpage sousgénérique du genre Tityus C.L. Koch, 1836 (Scorpiones, Buthidae) // Boletin de la Sociedad Entomológica Aragonesa. T.39. P.55-67.

Lourenço W.R., Eickstedt V.R.D. 1988. Considerações sobre a sistemática de Tityus costatus (Karsch, 1879), provavel espécie polimórfica de escorpião da Floresta Atlantica do Brasil (Scorpiones, Buthidae) // Iheringia, Sér. Zool. T.68. P.3-11.

Lourenço W.R., Ythier E., Stockmann M., Cloudsley-Thompson J.L. 2011. Polymorphism and hybridization in species of Hottentotta Birula, 1908 (Scorpiones: Buthidae) // Euscorpius. No.124. P.1-5.

Pocock R.I. 1889. On Isometrus americanus (Linn.), with a description of a new species of the genus // Annals and Magazine of Natural History. Ser.6. Vol.4. P.53-59.

Pocock R.I. 1893. Contributions to our knowledge of the arthropod fauna of the West Indies. Part I. Scorpiones and Pedipalpi, with a supplementary note upon the freshwater Descapoda of St. Vincent // Journal of the Linnaean Society. Vol.24. P.374-409.

Pocock R.I. 1897. Descriptions of some new species of scorpions of the genus Tityus, with notes upon some forms allied to $T$. americanus (Linn.) // Annals and Magazine of Natural History. Ser.6. Vol.19. P.510-521.

Stahnke H.L. 1970. Scorpion nomenclature and mensuration // Entomological News. Vol.81. P.297-316.

Teruel R. 2011. Redescription of Tityus pictus Pocock, 1893 and Tityus smithii Pocock, 1893, with notes on the Tityus species from the Lesser Antilles (Scorpiones: Buthidae) // Euscorpius. No.125. P.1-26.

Vachon M. 1952. Etudes sur les scorpions. Publications de l'Institut Pasteur d'Algérie, Alger. 482 p.

Vachon M. 1963. De l'utilité, en systématique, d'une nomenclature des dents des chélicères chez les scorpions // Bulletin du Muséum national d'Histoire naturelle, Paris. 2e sér. T.35. P.161-166.

Vachon M. 1974. Etude des caractères utilisés pour classer les familles et les genres de scorpions (Arachnides). 1. La trichobothriotaxie en arachnologie. Sigles trichobothriaux et types de trichobothriotaxie chez les scorpions // Bulletin du Muséum national d'Histoire naturelle, Paris. 3e sér. T.104. P.857-958.

Vachon M. 1975. Sur l'utilisation de la trichobothriotaxie du bras des pédipalpes des Scorpions (Arachnides) dans le classement des genres de la famille des Buthidae Simon // Comptes Rendus des Séances de l'Académie des Sciences. T.281. P.1597-1599.

Responsible editor S.I. Golovatch 